\title{
Bacteriophage Typing of the "Caulobacter Group"
}

\author{
J. A. BABINCHAK ${ }^{1}$ AND V. F. GERENCSER \\ Department of Microbiology, West Virginia University Medical Center, Morgantown, West Virginia 26506
}

\begin{abstract}
The phage types of 77 caulobacters were determined using 26 phages specific for this group of stalked bacteria. A standardized procedure, utilizing routine test dilutions, was used to eliminate an inhibition phenomenon which accounted for $53 \%$ of the positive reactions when undiluted phage lysates were tested. Among productive hosts, Caulobacter and Asticcacaulis phages were genus specific, although this specificity was not demonstrated by the inhibition reactions. However, Asticcacaulis $\phi 20 \mathrm{~S}$ was specific for only 2 of the 15 eccentrically stalked isolates tested. This limited specificity was common among the phages regardless of the cellular morphology of their host, since 7 of the 16 phages having productive hosts had no more than 2 hosts. Without phages that were specific for a broad host range of eccentrically stalked caulobacters, the separation of the genera Caulobacter and Asticcacaulis was not supported by bacteriophage typing.
\end{abstract}

Host range was one means used by Schmidt and Stanier (3) to characterize phages active against the stalked bacteria of the "Caulobacter group." The established host ranges were then used in a phage typing scheme for further characterization of the caulobacters (2).

Their 23 phages fell into seven groups on the basis of host range and serological properties. Six of these groups attacked only Caulobacter species, and one group attacked only Asticcacaulis species. This generic specificity of the phage was presented as a distinct difference between the genera in support of Poindexter's split of the family Caulobacteraceae into two genera: Caulobacter, for isolates with polar stalks and adhesive material at the distal end of the stalk, and Asticcacaulis, for isolates with eccentric stalks and separate polar adhesive material (2). Phage typing was also used to characterize species of Caulobacter. Schmidt, Stanier, and Poindexter used high-titer lysates for typing purposes, $10^{7}$ to $10^{8}$ plaque-forming units and $10^{6}$ to $10^{8}$ plaque-forming units, respectively.

The need for utilizing standardized methods for phage typing was initially shown to be essential for obtaining reliable and comparable results by Blair and Williams when phage typing Staphylococcus (1). Routine test dilutions (RTDs) of the phages were utilized and defined as the highest dilutions of the phages that just failed to give confluent lysis. High-titer lysates were shown to "inhibit" the growth of many Staphylococcus strains, but they failed to produce plaques when diluted. The concentration

\footnotetext{
1 Present address: National Marine Fisheries Service, Middle Atlantic Coastal Fisheries Center, Milford Laboratory, Milford, Conn. 06460.
}

of phage sufficient to give near-confluent lysis was between $5 \times 10^{4}$ and $2 \times 10^{5}$ particles per $\mathrm{ml}$. Confluent lysis was produced by a phage concentration between 2 and 10 times greater than that required to produce the RTD. The inhibition phenomenon was not reproducible enough to be useful in phage typing unless, in exceptional cases, these reactions provided the only indication of susceptibility to the phage.

In this investigation, the results of phage typing caulobacters were compared using hightiter lysates and RTDs as the typing methods.

Sixty-eight caulobacters isolated from a wide variety of environmental sources by our laboratory (unpublished data) and nine reference strains supplied by Poindexter were tested. Their laboratory numbers and sources are listed in Table 1. The schemes for the classification of caulobacter types are based primarily upon cellular morphology (2); therefore, the morphology of the caulobacters is listed in Table 2. The subvibrioid-bacteroid was a new morphological type isolated in our laboratory. The isolates were maintained on Poindexter complex medium (PYE) made with distilled water and supplemented with $0.01 \mathrm{mg}$ of riboflavine per ml, and cells for inoculation were used after 24 to $48 \mathrm{~h}$ of incubation at $30 \mathrm{C}$.

The sources of the 26 phages used for typing and their nucleic acid contents are given in Table 3. Nineteen were isolated and characterized by G. H. Szeyko (M.S. thesis, West Viriginia Univ., Morgantown, 1967), and each of Schmidt and Stanier's seven phage groups (3) is represented. These authors' original designations were modified to standardize the nomenclature for the present study.

The caulobacters were screened for sensitiv- 
TABLE 1. Caulobacter isolates used for bacteriophage typing

\begin{tabular}{|c|c|c|}
\hline $\begin{array}{c}\text { Caulobacter iso- } \\
\text { lates }\end{array}$ & Source & Isolated by \\
\hline$V-6,7,8$ & Pond water (W. Va.) & Gerencser \\
\hline & Pond water (W. Va.) & Gerencser \\
\hline CV $-17,18,20,37$ & Creek water (W. Va.) & Gerencser \\
\hline CV-27 & Creek water (W. Va.) & Gerencser \\
\hline CV-42, 46 & Intermittent creek (W. Va.) & Gerencser \\
\hline & Soil (W. Va.) & Gerencser \\
\hline CV.56 & Creek water (W. Va.) & Babinchak \\
\hline CV-70, 71, 72 & Creek water (W. Va.) & Babinchak \\
\hline $\begin{array}{c}\text { CV-65, 137, 165, } \\
166,167,168\end{array}$ & Pond water (W. Va.) & achak \\
\hline CV-74 & Creek water (W. Va.) & Babinchak \\
\hline $\begin{array}{l}\text { CV-76, } 113,114, \\
115\end{array}$ & (W. Va.) & chak \\
\hline CV-77 & Lake water (Ohio) & Babinchak \\
\hline CV-79, 80, 81, 83 & $\mathrm{r}(\mathrm{Pa})$ & chak \\
\hline CV $-84,86,87$ & Lake water (Pa.) & achak \\
\hline $88,89,126$ & ater (Ohio) & chak \\
\hline $0,91,92,93$ & Lake water (Ohio) & ichak \\
\hline 3,105 & Lake water (W. Va.) & chak \\
\hline 7,108 & River water (W. Va.) & chak \\
\hline CV-117, 118, 119 & Rain pool (W. Va.) & chak \\
\hline CV-129 & water $(\mathrm{Pa})$. & chak \\
\hline $\begin{array}{c}\text { CV-134, 135, 136, } \\
161,163,164\end{array}$ & Pond water (W. Va.) & Babinchak \\
\hline CV-139 & V. Va.) & Bab \\
\hline & Cre & \\
\hline $43,144,145$ & Lake water (W. Va.) & achak \\
\hline CV-155 & Creek water (W. Va.) & Babinchak \\
\hline $\begin{array}{l}\text { CV-156, 157, } 158, \\
\quad 159\end{array}$ & Pond water (W. Va.) & Babinchak \\
\hline CV.160 & ater (W. Va.) & $\mathrm{Br}$ \\
\hline CB-7 & ater (Calif.) & Poindexter \\
\hline CB11a, 13 & Pond water (Calif.) & Poindexter \\
\hline & water (Calif.) & Poindexter \\
\hline & Un & exter \\
\hline CB-27 & Pond water (Calif.) & Poindexter \\
\hline & Pond water (Calif.) & Poindexter \\
\hline CB-51 & Pond water (Calif.) & Poindexter \\
\hline CB-94 & Unknown & Poindexter \\
\hline
\end{tabular}

a The notation CV-6, 7, 8, etc., is to be read to mean CV-6, CV-7, CV-8, etc.

TABLE 2. Caulobacter cellular morphology

\begin{tabular}{cc} 
Caulobacter isolates & Morphology $^{a}$ \\
\hline
\end{tabular}

CV-6, 7, 8, 12, 20, 27, 37, 65,

$72,77,79,81,137,161,166$,

CB13, 15, $51^{b} \ldots \ldots \ldots$ Vibrioid

CV-17, 18, 42, 46, 70,76, 80,

$83,103,156,157,165,167$ Limonoid

CV-14, $91 \ldots \ldots \ldots \ldots$ Subvibrioid-bacteroid

CV-56, $105 \ldots \ldots \ldots \ldots \ldots$ Subvibrioid-fusiform

CV-54, 84, 87, 89, 90, 92, 93,

$107,108,126,113,114,115$,

$155,159,160,163,164$,

CB7, 11a, $94 \ldots \ldots \ldots$ Bacteroid

CV-71, 86, 88, 129, 158, CB27 Fusiform

CV-74, 117, 118, 119, 134,

$135,136,139,140,143,144$, Bacteroid, eccentric 145,168, AC20, 48 ... stalk

a Vibrioid = comma-shaped, curved rod; limonoid = lemon-shaped, plump and rounded; bacteroid = rod-shaped, blunt ends; fusiform = rod-shaped, tapered ends; subvibrioid $=$ mixture of vibrioid and bacteroid or fusiform.

'The notation CV-6, 7, 8, etc., is to be read to mean CV-6, CV-7, CV-8, etc.
TABLE 3. Caulobacter bacteriophages

\begin{tabular}{|c|c|c|}
\hline $\begin{array}{l}\text { Phage designa- } \\
\text { tions used in } \\
\text { this study }\end{array}$ & $\begin{array}{l}\text { Phage designations of } \\
\text { Szeyko, and Schmidt } \\
\text { and Stanier (3) }\end{array}$ & $\begin{array}{c}\text { Type of nucleic } \\
\text { acid }^{r}\end{array}$ \\
\hline \multicolumn{3}{|c|}{ Szeyko } \\
\hline$\phi 5 B$ & $\phi \mathrm{RP} 5$ & DNA \\
\hline$\phi 6$ & $\phi S F M 6$ & DNA \\
\hline$\phi 10 \mathrm{~A}$ & $\phi \mathrm{CSP} 10 \mathrm{~A}$ & DNA \\
\hline$\phi 10 \mathrm{~B}$ & $\phi \mathrm{CSP} 10 \mathrm{~B}$ & DNA \\
\hline$\phi 10 \mathrm{C}$ & $\phi \mathrm{CSP} 10 \mathrm{C}$ & DNA \\
\hline$\phi 10 \mathrm{D}$ & $\phi C S P 10 D$ & DNA \\
\hline$\phi 19 A$ & $\phi \mathrm{A}_{1} \mathrm{P} 19 \mathrm{~A}$ & DNA \\
\hline$\phi 19 B$ & $\phi A_{1} P 19 B$ & DNA \\
\hline$\phi 19 \mathrm{C}$ & $\phi \mathrm{DE} 19$ & DNA \\
\hline$\phi 19 D$ & $\phi \mathrm{LTA} 19$ & DNA \\
\hline$\phi 26$ & $\phi \mathrm{HC} 26$ & DNA \\
\hline$\phi 36 \mathrm{~A}$ & $\phi \mathrm{HC} 36 \mathrm{~A}$ & DNA \\
\hline$\phi 36 \mathrm{~B}$ & $\phi \mathrm{HC} 36 \mathrm{~B}$ & DNA \\
\hline$\phi 36 \mathrm{C}$ & $\phi B S C I I 36 A_{1}$ & DNA \\
\hline$\phi 36 \mathrm{D}$ & $\phi \mathrm{BSCII} 36 \mathrm{~A}_{2}$ & DNA \\
\hline$\phi 36 \mathrm{E}$ & $\phi \mathrm{BSCII}_{3} 6 \mathrm{~B}_{2}$ & DNA \\
\hline$\phi 43 \mathrm{~A}$ & фAF43 & DNA \\
\hline$\phi 43 B$ & $\phi \mathrm{BC} 43$ & DNA \\
\hline$\phi 47$ & $\phi \mathrm{AF} 47$ & DNA \\
\hline \multicolumn{3}{|c|}{ Schmidt and Stanier } \\
\hline$\phi 3 \mathrm{~S}$ & $\phi \mathrm{CB} 3$ & DNA \\
\hline$\phi 5 \mathrm{~S}$ & $\phi$ CB5 & RNA \\
\hline$\phi 6 \mathrm{~S}$ & $\phi$ CB6 & DNA \\
\hline$\phi 8 \mathrm{~S}$ & $\phi \mathrm{CB} 8 \mathrm{r}$ & RNA \\
\hline$\phi 13 \mathrm{~S}$ & $\phi \mathrm{CB} 13$ & DNA \\
\hline$\phi 20 \mathrm{~S}$ & $\phi \mathrm{AC} 20$ & DNA \\
\hline$\phi 23 S$ & $\phi C B 23 r$ & RNA \\
\hline
\end{tabular}

a Phages are available from V. F. Gerencser.

${ }^{\circ}$ G. H. Szeyko, M.S. thesis, West Virginia Univ., Morgantown, 1967.

- DNA, Deoxyribonucleic acid; RNA, ribonucleic acid.

TABLE 4. Reaction patterns of various Caulobacter isolates to lytic phages

\begin{tabular}{ll}
\hline \multicolumn{1}{c}{ Caulobacter isolates } & \multicolumn{1}{c}{ Phage patterns } \\
\hline CV-6, 7, 8, 12, 14, 159 & \multicolumn{1}{c}{6} \\
CV-17, 18, 37, 72, 86, 165, & $13 \mathrm{~S} / 26 / 43 \mathrm{~A} / 43 \mathrm{~B} / 47$ \\
167 & \\
CV-20 & $36 \mathrm{C} / 36 \mathrm{D} / 36 \mathrm{E}$ \\
CV-27 & $26 / 36 \mathrm{~B} / 36 \mathrm{C} / 36 \mathrm{D} / 36 \mathrm{E} /$ \\
& \multicolumn{1}{c}{$43 \mathrm{~A} / 43 \mathrm{~B} / 47$} \\
CV-42, 156, CB15 & $5 \mathrm{~S} / 13 \mathrm{~S} / 43 \mathrm{~A} / 43 \mathrm{~B} / 47$ \\
CV-46 & $5 \mathrm{~S} / 26$ \\
CV-54, 160 & $3 \mathrm{~S} / 6 / 6 \mathrm{~S}$ \\
CV-65, 103 & $26 / 43 \mathrm{~A} / 43 \mathrm{~B} / 47$ \\
CV-70, 77, 81, 137, 157, & $5 \mathrm{~S} / 13 \mathrm{~S} / 26 / 43 \mathrm{~A} / 43 \mathrm{~B} / 47$ \\
CB13, 51 & \\
CV-71 & $6 / 23 \mathrm{~S}$ \\
CV-76 & $3 \mathrm{~S} / 5 \mathrm{~S} / 43 \mathrm{~A} / 43 \mathrm{~B} / 47$ \\
CV-79 & $5 \mathrm{~S} / 43 \mathrm{~A} / 43 \mathrm{~B} / 47$ \\
CV-80, 161 & $5 \mathrm{~S}$ \\
CV-83 & $5 \mathrm{~S} / 26 / 43 \mathrm{~A} / 43 \mathrm{~B} / 47$ \\
CV-91 & $6 \mathrm{~S}$ \\
CV-155 & $3 \mathrm{~S} / 6 \mathrm{~S}$ \\
CB11a & $3 \mathrm{~S} / 6 \mathrm{~S} / 8 \mathrm{~S}$ \\
AC20, 48 & $20 \mathrm{~S}$ \\
CB27 & $23 \mathrm{~S}$ \\
CV-126 & $3 \mathrm{~S}$ \\
\hline
\end{tabular}

a The notation CV $-6,7,8$, etc., is to be read to mean $\mathrm{CV}-6, \mathrm{CV}-7, \mathrm{CV}-8$, etc. 
TABLE 5. Inhibition of Caulobacter isolates by phage lysates

\begin{tabular}{|c|c|}
\hline Caulobacter isolates & $\begin{array}{l}\text { Phage lysates causing } \\
\text { inhibition }\end{array}$ \\
\hline CV-91 & $\phi 5 \mathrm{~B}$ \\
\hline $\begin{array}{l}\text { CV-42, 74, 76, 91, 113, 114, } \\
\begin{array}{l}115,117,118,119,126, \\
129,134,135,158, \text { CB } 11 \mathrm{a} \\
27,94^{a}\end{array}\end{array}$ & $\phi 6$ \\
\hline $\begin{array}{l}\mathrm{CV}-46,70,72,77,79,80,81 \\
\quad 83,156\end{array}$ & $\phi 10 \mathrm{~A}, 10 \mathrm{C}, 10 \mathrm{D}$ \\
\hline $\begin{array}{l}\text { CV-46, } 70,72,77,79,80,81 \\
\quad 83\end{array}$ & $\phi 10 \mathrm{~B}$ \\
\hline CV-37, 105 & $\phi 19 A, 19 B, 19 C, 19 D$ \\
\hline $\begin{array}{l}\text { CV-20, 42, 56, 79, 105, 156, } \\
\quad 161, \mathrm{CB} 15\end{array}$ & $\phi 26$ \\
\hline CV-27 & $\phi 36 \mathrm{~A}$ \\
\hline CV-20 & $\phi 36 \mathrm{~B}$ \\
\hline $\begin{array}{l}\text { CV-6, 7, 8, 12,14, 20,46,56, } \\
\quad 80,105,115,160,161\end{array}$ & $\phi 43 \mathrm{~A}, 43 \mathrm{~B}$ \\
\hline $\begin{array}{l}\text { CV-7, 8,12,14, 20, 46, 56, } \\
\quad 105,160,161\end{array}$ & $\phi 47$ \\
\hline $\begin{array}{r}\text { CV-42, 72, 90, 91, 113, 114, } \\
137,156,159, \mathrm{CB} 7,15,51\end{array}$ & $\phi 3 \mathrm{~S}$ \\
\hline CV -72 & $\phi 5 \mathrm{~S}$ \\
\hline $\begin{array}{l}\text { CV-42, } 72,76,77,81,83,90 \\
\begin{array}{l}108,113,114,115,126, \\
137,156,157,159, \mathrm{CB} 7 \\
15,51\end{array}\end{array}$ & $\phi 6 \mathrm{~S}$ \\
\hline $\begin{array}{l}\mathrm{CV}-6,7,8,12,14,20,27,46 \\
56,65,76,79,80,83,103 \\
105,161\end{array}$ & $\phi 13 \mathrm{~S}$ \\
\hline $\begin{array}{l}\text { CV-6, } 7,8,12,14,54,74,76, \\
88,115,126,129,134,135, \\
\quad 136, \text { CB11a }\end{array}$ & $\phi 20 \mathrm{~S}$ \\
\hline
\end{tabular}

a The notation CV $-42,74,76$, etc., is to be read to mean CV-42, CV-74, CV-76, etc.

ity to the phages by placing a drop of undiluted phage lysate on a PYE overlayer inoculated with 0.1 to $0.2 \mathrm{ml}$ of a bacterial strain. Strains showing sensitivity were then typed in the same manner with seven consecutive decimal dilutions of the active phage lysate. Inhibition was differentiated from phage lysis by the abrupt disappearance of lysate action without plaque formation.

The comparison of the two phage typing methods revealed that the inhibition phenomenon accounted for $53 \%$ of the positive reactions observed when high-titer lysates were utilized. The phage patterns of caulobacters determined with RTDs are listed in Table 4 . The caulobacters which were inhibited by hightiter lysates, but did not produce plaques with RTDs, are listed with the corresponding active phage lysate in Table 5.

Since Schmidt and Stanier (3) and Poindexter (2) utilized high-titer phage lysates for typing purposes, the inhibition phenomenon would be included in their host ranges. Indeed, two caulobacters, CB-7 and CB-15, which were reported to be hosts for $\phi 6 \mathrm{~S}$ (3), were inhibited only by the high-titer lysate in this study.

The significance of the inhibition phenomenon on the taxonomic relationship between the two genera, Caulobacter and Asticcacaulis, needs to be investigated, since 12 polar stalked caulobacters were inhibited by the lysate of Asticcacaulis $\phi 20 \mathrm{~S}$ and 6 eccentrically stalked strains were inhibited by the lysate of Caulobacter $\phi 6$. This finding differed significantly with the absolute generic specificity of the phage found in the Schmidt and Stanier study (3).

Fifteen of the 16 phages which had productive hosts and 10 phages which had no productive hosts among the 77 caulobacters tested had members of the genus Caulobacter as propagating strains. The presence of both ribonucleic acid and deoxyribonucleic acid phage and broad and narrow host ranges among this group of phages would make phage typing a valuable tool for classifying the genus Caulobacter. However, to insure reliable and comparable results, the predominance of the inhibition phenomenon established the need for utilizing RTDs and standardized procedures for phage typing caulobacters, as outlined for the phage typing of Staphylococcus (1).

A broad spectrum of phages specific for eccentrically stalked caulobacters is needed similar to the phage group specific for Caulobacter strains. Only three phages have been reported for eccentrically stalked caulobacters, and these could represent reisolates of the same phage. Asticcacaulis $\phi 20 \mathrm{~S}$ represents these phages which were isolated from the same environmental source and were indistinguishable in characterization studies (3). This phage group was specific for 3 of Poindexter's 5 eccentrically stalked strains, but none of the 13 Asticcacaulis strains isolated by this laboratory served as host for Asticcacaulis $\phi 20 \mathrm{~S}$.

\section{ACKNOWLEDGMENTS}

We are grateful to J. S. Poindexter and J. M. Schmidt for supplying caulobacters and bacteriophages from their collections.

\section{REPRINT REQUESTS}

Address reprint requests to: Mr. John Babinchak, National Marine Fisheries Service, Middle Atlantic Coastal Fisheries Center, Milford Laboratory, Milford, Conn. 06460 .

\section{LITERATURE CITED}

1. Blair, J. E., and R. E. O. Williams. 1961. Phage typing of Staphylococci. Bull W.H.O. 24:771-784.

2. Poindexter, J. S. 1964. Biological properties and classification of the Caulobacter group. Bacteriol. Rev. 28:231-295.

3. Schmidt, J. M., and R. Y. Stanier. 1965. Isolation and characterization of bacteriophages active against stalked bacteria. J. Gen. Microbiol. 39:95-107. 